Western University

Scholarship@Western

$7-1-2020$

\title{
Consideration of pannexin 1 channels in covid- 19 pathology and treatment
}

\author{
Leigh Anne Swayne \\ University of Victoria \\ Scott R. Johnstone \\ Virginia Tech Carilion School of Medicine \\ Chen Seng $\mathrm{Ng}$ \\ The University of British Columbia \\ Juan C. Sanchez-Arias \\ University of Victoria \\ Miranda E. Good \\ Tufts Medical Center
}

See next page for additional authors

Follow this and additional works at: https://ir.lib.uwo.ca/anatomypub

Part of the Anatomy Commons, and the Cell and Developmental Biology Commons

\section{Citation of this paper:}

Swayne, Leigh Anne; Johnstone, Scott R.; Ng, Chen Seng; Sanchez-Arias, Juan C.; Good, Miranda E.; Penuela, Silvia; Lohman, Alexander W.; Wolpe, Abigail G.; Laubach, Victor E.; Michael Koval, X.; and Isakson, Brant E., "Consideration of pannexin 1 channels in covid-19 pathology and treatment" (2020). Anatomy and Cell Biology Publications. 331.

https://ir.lib.uwo.ca/anatomypub/331 


\section{Authors}

Leigh Anne Swayne, Scott R. Johnstone, Chen Seng Ng, Juan C. Sanchez-Arias, Miranda E. Good, Silvia Penuela, Alexander W. Lohman, Abigail G. Wolpe, Victor E. Laubach, X. Michael Koval, and Brant E.

Isakson 


\title{
PERSPECTIVES | The Pathophysiology of COVID-19 and SARS-CoV-2 Infection
}

\section{Consideration of Pannexin 1 channels in COVID-19 pathology and treatment}

\author{
(D) Leigh Anne Swayne, ${ }^{1}$ (1) Scott R. Johnstone, ${ }^{2,3}$ Chen Seng Ng, ${ }^{4,5}$ Juan C. Sanchez-Arias, ${ }^{1}$ \\ Miranda E. Good, ${ }^{6}$ Silvia Penuela, ${ }^{7}$ Alexander W. Lohman, ${ }^{8,9}$ Abigail G. Wolpe, ${ }^{10,11}$ \\ (1) Victor E. Laubach, ${ }^{12,13}$ (1) Michael Koval, ${ }^{14}$ and (다) Brant E. Isakson ${ }^{10,13}$ \\ ${ }^{1}$ Division of Medical Sciences, University of Victoria, Victoria, British Columbia, Canada; ${ }^{2}$ Fralin Biomedical Research \\ Institute at Virginia Tech Carilion Center for Heart and Reparative Medicine Research, Virginia Tech, Roanoke, Virginia; \\ ${ }^{3}$ Department of Biological Sciences, Virginia Tech, Roanoke, Virginia; ${ }^{4}$ Department of Pathology and Laboratory Medicine, \\ University of British Columbia, Vancouver, British Columbia, Canada; ${ }^{5}$ Centre for Heart Lung Innovation, St. Paul's \\ Hospital, University of British Columbia, Vancouver, British Columbia, Canada; ${ }^{6}$ Molecular Cardiology Research Institute, \\ Tufts Medical Center, Boston, Massachusetts; ${ }^{7}$ Department of Anatomy and Cell Biology, University of Western Ontario, \\ London, Ontario, Canada; ${ }^{8}$ Department of Cell Biology and Anatomy, University of Calgary, Calgary, Alberta, Canada; \\ ${ }^{9}$ Hotchkiss Brain Institute, University of Calgary, Calgary, Alberta, Canada; ${ }^{10}$ Robert M. Berne Cardiovascular Research \\ Center, University of Virginia School of Medicine, Charlottesville, Virginia; ${ }^{11}$ Department of Cell Biology, University of \\ Virginia School of Medicine, Charlottesville, Virginia; ${ }^{12}$ Department of Surgery, University of Virginia School of Medicine, \\ Charlottesville, Virginia; ${ }^{13}$ Department of Molecular Physiology and Biophysics, University of Virginia School of Medicine, \\ Charlottesville, Virginia; and ${ }^{14}$ Department of Medicine, Division of Pulmonary, Allergy, Critical Care and Sleep Medicine, \\ Emory University School of Medicine, Atlanta, Georgia
}

Submitted 13 April 2020; accepted in final form 31 May 2020

\section{INTRODUCTION}

Pannexin 1 (PANX1) is a ubiquitously expressed, channelforming protein found in a number of tissues throughout the body (e.g., lung, vasculature, liver, central nervous system, immune system) that is important in many key physiological and immune responses $(18,55)$. PANX1 channels passively flux ATP (predominantly), multiple metabolites, and likely other small anions $(37,39)$. PANX1 channels regulate inflammation and host responses to several pathogens, including viruses $(36,42,53)$. While there is currently no evidence suggesting novel severe acute respiratory syndrome coronavirus 2 (SARS-CoV-2) and PANX1 directly interact, there is an urgent need for therapeutic strategies, especially those targeting the hyperinflammation and cytokine storm that occurs in severe cases of COVID-19 $(27,41)$. Here we argue that PANX1, and drugs known to target PANX1 (including the FDA-approved drug probenecid), should be the focus of further investigation in the context of SARS-CoV-2 infection and its associated pathology in COVID-19 patients.

\section{REGULATION OF INFLAMMATION BY PANX1 IN THE CONTEXT OF COVID-19}

COVID-19 patients frequently present with hypoxemia and dyspnea requiring supportive oxygen therapy before reaching a more severe hyperinflammatory phase of the disease and acute respiratory distress syndrome (ARDS) $(4,11,26)$. Control of the early phase of innate immunity, enabling a productive adaptive immune response, is critical to ensure patient recovery (56). It has been suggested that immunosuppression treatment for COVID-19 patients displaying hyperinflammation could limit disease progression as well as limit viral entry (38,

Correspondence: B. E. Isakson (brant@ virginia.edu).
65). There are several lines of evidence demonstrating that PANX1 channel opening (and release of ATP) enhances inflammatory responses, including in the systemic endothelium (lung microvasculature), lung epithelium, olfactory epithelium, and the parenchyma of several tissues throughout the body $(13,17,22,29,31,35,51)$. Multiple studies have shown that PANX1 signaling exacerbates inflammatory responses through: being activated and enhanced by $\mathrm{TNF} \alpha-$ receptor signaling, being implicated in the inflammasome, involvement in leukocyte recruitment, and playing a role in the production and secretion of proinflammatory cytokines such as IL-1 $\beta$ and IL- 6 by endothelial cells and other cell types $(12,22$, 24, 35, 41, 51, 63). Given that disruption (both deletion and inhibition) of PANX1 in endothelial cells significantly reduces inflammation in several injury models $(22,28,51,59)$, PANX1 represents a potential target in reducing inflammatory burden and the damaging effects of the cytokine storm in COVID-19 patients. With intense vascular inflammation observed in severe cases of SARS-CoV-2 infection $(14,66)$, effective treatments to dampen hyperinflammation represent an urgent treatment need.

Of particular interest to SARS-CoV-2 infection, endothelial PANX1 has been shown to play a key role in regulating lung vascular inflammation and edema in response to ischemia/ reperfusion injury (51). Control of pulmonary edema is crucial in limiting the severity of ARDS (58). In this light, TRPV4 channels in the alveolo-capillary unit were recently proposed to be a pharmacologically tractable target for treatment of ARDS associated with COVID-19 (30). In addition to direct control of lung barrier function by TRPV4 inhibitors, there is evidence that TRPV4 channels could induce PANX1 channel activity $(45,49,50)$, suggesting that PANX1 inhibitors might improve the efficacy of TRPV4 channel inhibitors. Defining the molecular basis for coordinated regulation of TRPV4 and PANX1 
channels should facilitate the design of therapeutic approaches attenuating this signaling axis in treatment of COVID-19.

In addition to its general role in inflammatory signaling, PANX1 (either directly or pharmacologically) has been implicated in host responses to viral infection and regulation of virus life cycle [e.g., human immunodeficiency virus (HIV), hepatitis B, influenza, vesicular stomatitis virus (VSV), etc.]. PANX1 is expressed in key cells and tissues targeted by SARS-CoV-2, including airway epithelium (46), lung endothelium $(34,51)$, and neurons (7) (as well as many cell types and tissues throughout the body). In the case of $\operatorname{HIV}(36,42,53)$, ATP release via PANX1 channels following viral binding stimulates purinergic signaling pathways that enhance viral binding, uptake, and replication. Extracellular ATP has also been linked to viral infection and sequelae: it triggers HIV-1 release from cells (23), is released from cells following VSV infection (64), and is linked to ARDS associated with adenoviral infection (32). How extracellular ATP and purinergic receptors generally regulate entry of viruses has not yet been elucidated, and no links have yet been made between extracellular ATP and coronaviruses. Coronavirus membrane fusion can occur at the plasma membrane or at endosomes $(25,54,62)$. Coronaviruses have been shown to enter cells via macropinocytosis, a clathrin- and caveolin-independent process $(20,57)$. Notably, elevated extracellular ATP can also trigger interactions between PANX1 and P2X7 receptors and their internalization to endosomes through a clathrin- and caveolin-independent process reminiscent of micropinocytosis $(6,8)$. If direct links between PANX1 and the SARS-CoV-2 life cycle are identified, targeting PANX1 could help mitigate the significant viral titers observed with COVID-19 that result in endothelial damage and neuronal tissue accumulation $(33,44,68)$.

The above snapshot of PANX1 regulation of inflammatory cascades and viral pathologies supports the need for further study to explore potential direct links to COVID-19. From a therapeutics standpoint for COVID-19, PANX1 also has some intriguing preexisting ties and potential. For instance, nucleotide antiviral drugs, of which remdesivir has shown some effectiveness, may exhibit anti-PANX1 activity. Moreover, probenecid is an FDA-approved drug that blocks PANX1, often recapitulating the effects of PANXI deletion. Given the evidence described below, we argue PANX1 blockers should be considered in COVID-19 preclinical drug repurposing studies.

\section{PANX1 AND NUCLEOTIDE ANALOG ANTIVIRALS}

Nucleotide analog antivirals are designed to compete for incorporation into newly synthesized viral nucleic acid chains thereby disrupting virus life cycles. In preliminary analyses of ongoing clinical trials $(1,10)$, remdesivir, first described in the treatment of Ebola, has shown modest effects in reducing time to recovery (2). With respect to PANX1, tenofovir (not under consideration for COVID-19 but a nucleotide analog antiviral), used in the treatment of hepatitis B and HIV, inhibited PANX1-mediated ATP release in a mouse macrophage cell line (RAW264.7 cells) and a human liver cell line (HepG2 cells) (19). It is possible the inhibitory action of tenofovir on PANX1 could be via an intracellular mechanism, due to the fact that the drug is metabolized into a nucleotide analog inside the cell. However, high concentrations of extracellular ATP inhibit PANX1 and lead to PANX1 internalization (8), raising another possibility: that the active form of the drug might somehow be released into the extracellular space and block the channel from an external site, like ATP. In light of these prior findings, it could be valuable to determine whether, like tenofovir, remdesivir also impacts both PANX1 channel activity and possibly PANX1-associated inflammatory signaling in COVID-19. This work would be facilitated by the recent advances in our understanding of the PANX1 structure, including identification of key extracellular regulatory residues $(16$, 39). Remdesivir's effects on PANX1 channels are not known but would merit investigation in light of the blocking effect of the related drug, tenofovir, and the established role of PANX1 in inflammation and regulation of virus life cycles.

\section{REPURPOSED FDA-APPROVED DRUGS THAT BLOCK PANX1 FOR COVID-19 TREATMENT?}

Probenecid (commercially known as Probalan, Benemid, or Benuryl) is an FDA-approved treatment for gout that is also a well-established PANX1 inhibitor (61). Influenza A viral infection and lung viral load were attenuated following probenecid treatment both in vitro and in vivo (43). Probenecid also decreased inflammasome-dependent IL-1 $\beta$ secretion from macrophages in vitro (15), reduced the inflammatory response in sepsis (55), and suppressed hyperinflammation resulting from severe influenza A infection in mice (48). Additionally, probenecid treatment lowered the required dose of another antiviral medication, oseltamivir (43), likely due to probenecid's ability to increase plasma levels of the antiviral drug (47). Note that probenecid also inhibits $\mathrm{P} 2 \mathrm{X} 7$ receptors (3), which is also likely to contribute to the antiviral and anti-inflammatory activity. Probenecid has also been shown to have a protective effect in ischemia/reperfusion injury by inhibiting secretion of the lysosomal cathepsin proteases (60). This suggests a mechanism of protection from SARS-CoV-2 infection, since cathepsins promote coronavirus infection through proteolytic cleavage of the spike protein (67). Thus, considering probenecid is

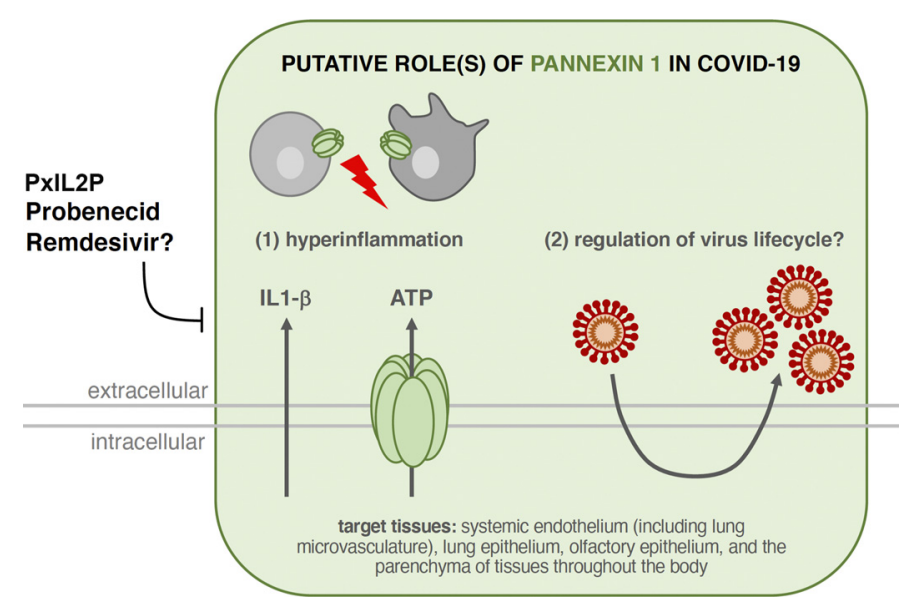

Fig. 1. Possible roles for Pannexin 1 (PANX1) in COVID-19 pathology. Pannexin intracellular loop 2 peptide (PxIL2P) could potentially be commercialized for specific PANX1 inhibition of inflammatory cues (e.g., IL-1 $\beta$ ). Probenecid, an FDA-approved drug used in the treatment of gout, could help dampen the hyperinflammation observed in COVID-19 and could also have an impact on the life cycle of the virus. In addition to affecting the life cycle of the virus, remdesivir could potentially impact inflammation through blocking PANX1. 
relatively well tolerated, has demonstrated action on viral infection-associated inflammation, and decreases required doses of other drugs, it could be of interest to investigate its potential use for COVID-19.

Another PANX1 channel-inhibiting FDA-approved drug with potential for the treatment of COVID-19 is spironolactone, an aldosterone antagonist used initially as a diuretic for the treatment of high blood pressure (21). In addition to its potential benefit as a PANX1 blocker in the context of SARS-CoV-2 infection, it was recently suggested that spironolactone may be useful in COVID-19-associated ARDS patients with hypertension (9). It was postulated that spironolactone might selectively increase plasma levels of the spike protein receptor $\mathrm{ACE} 2(27,52)$, increasing the proportion of circulating to lung-endothelial cell-membrane-associated ACE2 levels (thereby minimizing lung infection), as a safer mechanism of action than ACE inhibitors that target cell-bound ACE2 (9). Further investigation is needed to determine whether this is the case and to determine whether there are benefits of the PANX1-inhibiting action of spironolactone in the context of COVID-19.

\section{A POTENTIAL FOR THE DIRECT TARGETING OF PANX1 CHANNELS}

Finally, if PANX1 is found to be involved in the primary regulation of SARS-CoV-2 infectivity and inflammatory responses, it may also be worth considering direct targeting of the channel functions. Currently there are no FDA-approved PANX1-specific blockers, although a PANX1-specific inhibitor peptide, pannexin intracellular loop 2 peptide (PxIL2P), has shown promise in reducing inflammatory responses in vitro and in vivo $(35,63)$. PxIL2P contains a short mimetic sequence for the IL2 region of PANX1 attached to an HIV-TAT transactivation protein (5) that binds to the second intracellular loop of PANX1 and blocks channel release of ATP, altering intracellular $\mathrm{Ca}^{2+}$ flux $(35,63)$. Using PxIL2P in cultured endothelial cells blocks PANX1-regulated expression and release of cytokines including IL-1 $\beta$ and CxCL10 and limits monocyte adhesion in the vasculature $(35,63)$. Thus direct targeting of the PANX1 channel may have functionality in reducing SARS-CoV-2 infectivity and vascular inflammatory responses in COVID19 patients.

\section{CONCLUSION}

Although there are currently no direct lines of evidence linking PANX1 to COVID-19, the central role of PANX1 in regulating inflammation, and more generally viral infection, provides a rationale supporting preclinical investigation of PANX1 and repurposing of approved PANX1-targeting drugs like probenecid as potential treatments. A summary of our perspective is illustrated in Fig. 1. We postulate that evaluating current COVID-19 treatment protocols for their effects on PANX1 may lead to improved combination therapeutic approaches by including specific PANX1 inhibitors as part of a treatment regimen.

\section{GRANTS}

Support for researching and writing this Perspective was from the Canadian Institutes of Health Research (MOP142215) and from the Natural Sciences and Engineering Research Council (RGPIN-2017-03889) (L.A.S.), American Heart Association Career Development Award 19CDA34630036 (S.R.J.), as well as NIH R00-HL143165 (M.E.G.), NIH R01-HL137112 (M.K. and B.E.I.), NIH R01-HL120840 (B.E.I.), and NIH R01-AA025854 (M.K.).

\section{DISCLOSURES}

No conflicts of interest, financial or otherwise, are declared by the authors.

\section{AUTHOR CONTRIBUTIONS}

L.A.S. and B.E.I. conceived and designed research; L.A.S., S.R.J., C.S.N., J.C.S.-A., M.E.G., S.P., A.W.L., A.G.W., V.E.L., M.K., and B.E.I. analyzed data; L.A.S. and B.E.I. interpreted results of experiments; L.A.S. and B.E.I. drafted manuscript; L.A.S., S.R.J., C.S.N., J.C.S.-A., M.E.G., S.P., A.W.L., A.G.W., V.E.L., M.K., and B.E.I. edited and revised manuscript; L.A.S., S.R.J., C.S.N., J.C.S.-A., M.E.G., S.P., A.W.L., A.G.W., V.E.L., M.K., and B.E.I. approved final version of manuscript.

\section{REFERENCES}

1. Al-Tawfiq JA, Al-Homoud AH, Memish ZA. Remdesivir as a possible therapeutic option for the COVID-19. Travel Med Infect Dis 34: 101615, 2020. doi:10.1016/j.tmaid.2020.101615.

2. Beigel JH, Tomashek KM, Dodd LE, Mehta AK, Zingman BS, Kalil AC, Hohmann E, Chu HY, Luetkemeyer A, Kline S, Lopez de Castilla D, Finberg RW, Dierberg K, Tapson V, Hsieh L, Patterson TF, Paredes R, Sweeney DA, Short WR, Touloumi G, Lye DC, Ohmagari N, Oh MD, Ruiz-Palacios GM, Benfield T, Fätkenheuer G, Kortepeter MG, Atmar RL, Creech CB, Lundgren J, Babiker AG, Pett S, Neaton JD, Burgess TH, Bonnett T, Green M, Makowski M, Osinusi A, Nayak S, Lane HC; ACTT-1 Study Group Members. Remdesivir for the treatment of Covid-19 - preliminary report. $N$ Engl J Med NEJMoa2007764, 2020. doi:10.1056/NEJMoa2007764.

3. Bhaskaracharya A, Dao-Ung P, Jalilian I, Spildrejorde M, Skarratt KK, Fuller SJ, Sluyter R, Stokes L. Probenecid blocks human P2X7 receptor-induced dye uptake via a pannexin-1 independent mechanism. PLoS One 9: e93058, 2014. doi:10.1371/journal.pone.0093058.

4. Bhatraju PK, Ghassemieh BJ, Nichols M, Kim R, Jerome KR, Nalla AK, Greninger AL, Pipavath S, Wurfel MM, Evans L, Kritek PA, West TE, Luks A, Gerbino A, Dale CR, Goldman JD, O'Mahony S, Mikacenic C. Covid-19 in critically ill patients in the Seattle region case series. $N$ Engl J Med 382: 2012-2022, 2020. doi:10.1056/ NEJMoa2004500.

5. Billaud M, Chiu YH, Lohman AW, Parpaite T, Butcher JT, Mutchler SM, DeLalio LJ, Artamonov MV, Sandilos JK, Best AK, Somlyo AV, Thompson RJ, Le TH, Ravichandran KS, Bayliss DA, Isakson BE. A molecular signature in the pannexin1 intracellular loop confers channel activation by the $\alpha 1$ adrenoreceptor in smooth muscle cells. Sci Signal 8: ra17, 2015. doi:10.1126/scisignal.2005824.

6. Boyce AK, Kim MS, Wicki-Stordeur LE, Swayne LA. ATP stimulates pannexin 1 internalization to endosomal compartments. Biochem $J$ 470: 319-330, 2015. doi:10.1042/BJ20141551.

7. Boyce AKJ, Epp AL, Nagarajan A, Swayne LA. Transcriptional and post-translational regulation of pannexins. Biochim Biophys Acta Biomembr 1860: 72-82, 2018. doi:10.1016/j.bbamem.2017.03.004.

8. Boyce AKJ, Swayne LA. P2X7 receptor cross-talk regulates ATPinduced pannexin 1 internalization. Biochem $J$ 474: 2133-2144, 2017. doi:10.1042/BCJ20170257.

9. Cadegiani FA. Can spironolactone be used to prevent COVID-19-induced acute respiratory distress syndrome in patients with hypertension? Am J Physiol Endocrinol Metab 318: E587-E588, 2020. doi:10.1152/ajpendo. 00136.2020 .

10. Chan KW, Wong VT, Tang SCW. COVID-19: an update on the epidemiological, clinical, preventive and therapeutic evidence and guidelines of integrative Chinese-Western medicine for the management of 2019 novel coronavirus disease. Am J Chin Med 48: 737-762, 2020. doi:10.1142/S0192415X20500378.

11. Chen G, Wu D, Guo W, Cao Y, Huang D, Wang H, Wang T, Zhang X, Chen H, Yu H, Zhang X, Zhang M, Wu S, Song J, Chen T, Han M, Li S, Luo X, Zhao J, Ning Q. Clinical and immunological features of severe and moderate coronavirus disease 2019. J Clin Invest 130: $2620-$ 2629, 2020. doi:10.1172/JCI137244.

12. Chen KW, Demarco B, Broz P. Pannexin-1 promotes NLRP3 activation during apoptosis but is dispensable for canonical or non-canonical inflammasome activation. Eur J Immunol 50: 170-177, 2019. doi:10.1002/eji. 201948254. 
13. Chen W, Zhu S, Wang Y, Li J, Qiang X, Zhao X, Yang H, D'Angelo J, Becker L, Wang P, Tracey KJ, Wang H. Enhanced macrophage Pannexin 1 expression and hemichannel activation exacerbates lethal experimental sepsis. Sci Rep 9: 160, 2019. doi:10.1038/s41598-01837232-z.

14. Clerkin KJ, Fried JA, Raikhelkar J, Sayer G, Griffin JM, Masoumi A, Jain SS, Burkhoff D, Kumaraiah D, Rabbani L, Schwartz A, Uriel N. COVID-19 and cardiovascular disease. Circulation 141: 1648-1655, 2020. doi:10.1161/CIRCULATIONAHA.120.046941.

15. Crespo Yanguas S, Willebrords J, Johnstone SR, Maes M, Decrock E, De Bock M, Leybaert L, Cogliati B, Vinken M. Pannexin1 as mediator of inflammation and cell death. Biochim Biophys Acta Mol Cell Res 1864: 51-61, 2017. doi:10.1016/j.bbamcr.2016.10.006.

16. Deng Z, He Z, Maksaev G, Bitter RM, Rau M, Fitzpatrick JAJ, Yuan P. Cryo-EM structures of the ATP release channel pannexin 1. Nat Struct Mol Biol 27: 373-381, 2020. doi:10.1038/s41594-020-0401-0.

17. Do BH, Ohbuchi T, Wakasugi T, Koizumi H, Yokoyama M, Hohchi N, Suzuki H. Acetylcholine-induced ciliary beat of the human nasal mucosa is regulated by the pannexin-1 channel and purinergic P2X receptor. Am J Rhinol Allergy 32: 217-227, 2018. doi:10.1177/1945892418770292.

18. Esseltine JL, Laird DW. Next-generation connexin and pannexin cell biology. Trends Cell Biol 26: 944-955, 2016. doi:10.1016/j.tcb.2016.06. 003.

19. Feig JL, Mediero A, Corciulo C, Liu H, Zhang J, Perez-Aso M, Picard L, Wilder T, Cronstein B. The antiviral drug tenofovir, an inhibitor of Pannexin-1-mediated ATP release, prevents liver and skin fibrosis by downregulating adenosine levels in the liver and skin. PLoS One 12: e0188135, 2017. doi:10.1371/journal.pone.0188135.

20. Freeman MC, Peek CT, Becker MM, Smith EC, Denison MR. Coronaviruses induce entry-independent, continuous macropinocytosis. MBio 5: e01340-e14, 2014. doi:10.1128/mBio.01340-14.

21. Good ME, Chiu YH, Poon IKH, Medina CB, Butcher JT, Mendu SK, DeLalio LJ, Lohman AW, Leitinger N, Barrett E, Lorenz UM, Desai BN, Jaffe IZ, Bayliss DA, Isakson BE, Ravichandran KS. Pannexin 1 channels as an unexpected new target of the anti-hypertensive drug spironolactone. Circ Res 122: 606-615, 2018. doi:10. 1161/CIRCRESAHA.117.312380.

22. Good ME, Eucker SA, Li J, Bacon HM, Lang SM, Butcher JT, Johnson TJ, Gaykema RP, Patel MK, Zuo Z, Isakson BE. Endothelial cell Pannexin 1 modulates severity of ischemic stroke by regulating cerebral inflammation and myogenic tone. JCI Insight 3: e96272, 2018. doi:10.1172/jci.insight.96272.

23. Graziano F, Desdouits M, Garzetti L, Podini P, Alfano M, Rubartelli A, Furlan R, Benaroch P, Poli G. Extracellular ATP induces the rapid release of HIV-1 from virus containing compartments of human macrophages. Proc Natl Acad Sci USA 112: E3265-E3273, 2015. doi:10.1073/ pnas. 1500656112 .

24. Gulbransen BD, Bashashati M, Hirota SA, Gui X, Roberts JA, MacDonald JA, Muruve DA, McKay DM, Beck PL, Mawe GM, Thompson RJ, Sharkey KA. Activation of neuronal P2X7 receptor-pannexin-1 mediates death of enteric neurons during colitis. Nat Med 18: 600-604, 2012. doi: $10.1038 / \mathrm{nm} .2679$

25. Hoffmann M, Kleine-Weber H, Schroeder S, Krüger N, Herrler T, Erichsen S, Schiergens TS, Herrler G, Wu NH, Nitsche A, Müller MA, Drosten C, Pöhlmann S. SARS-CoV-2 cell entry depends on ACE2 and TMPRSS2 and is blocked by a clinically proven protease inhibitor. Cell 181: 271-280.e8, 2020. doi:10.1016/j.cell.2020.02.052.

26. Huang C, Wang Y, Li X, Ren L, Zhao J, Hu Y, Zhang L, Fan G, Xu J, Gu X, Cheng Z, Yu T, Xia J, Wei Y, Wu W, Xie X, Yin W, Li H, Liu M, Xiao Y, Gao H, Guo L, Xie J, Wang G, Jiang R, Gao Z, Jin Q, Wang J, Cao B. Clinical features of patients infected with 2019 novel coronavirus in Wuhan, China. Lancet 395: 497-506, 2020. doi:10.1016/ S0140-6736(20)30183-5.

27. Hui KPY, Cheung MC, Perera RAPM, Ng KC, Bui CHT, Ho JCW, Ng MMT, Kuok DIT, Shih KC, Tsao SW, Poon LLM, Peiris M, Nicholls JM, Chan MCW. Tropism, replication competence, and innate immune responses of the coronavirus SARS-CoV-2 in human respiratory tract and conjunctiva: an analysis in ex-vivo and in-vitro cultures. Lancet Respir Med. In press. doi:10.1016/S2213-2600(20)30193-4.

28. Jankowski J, Perry HM, Medina CB, Huang L, Yao J, Bajwa A, Lorenz UM, Rosin DL, Ravichandran KS, Isakson BE, Okusa MD. Epithelial and endothelial pannexin1 channels mediate AKI. J Am Soc Nephrol 29: 1887-1899, 2018. doi:10.1681/ASN.2017121306.
29. Krick S, Wang J, St-Pierre M, Gonzalez C, Dahl G, Salathe M. Dual oxidase 2 (Duox2) regulates pannexin 1-mediated ATP release in primary human airway epithelial cells via changes in intracellular $\mathrm{pH}$ and not H2O2 production. J Biol Chem 291: 6423-6432, 2016. doi:10.1074/jbc. M115.664854.

30. Kuebler WM, Jordt SE, Liedtke WB. Urgent reconsideration of lung edema as a preventable outcome in COVID-19: inhibition of TRPV4 represents a promising and feasible approach. Am J Physiol Lung Cell Mol Physiol 318: L1239-L1243, 2020. doi:10.1152/ajplung.00161.2020.

31. Kurtenbach S, Whyte-Fagundes P, Gelis L, Kurtenbach S, Brazil E, Zoidl C, Hatt H, Shestopalov VI, Zoidl G. Investigation of olfactory function in a Panx1 knock out mouse model. Front Cell Neurosci 8: 266, 2014. doi:10.3389/fncel.2014.00266.

32. Lee BH, Hwang DM, Palaniyar N, Grinstein S, Philpott DJ, Hu J. Activation of P2X(7) receptor by ATP plays an important role in regulating inflammatory responses during acute viral infection. PLoS One 7: e35812, 2012. doi:10.1371/journal.pone.0035812.

33. Li YC, Bai WZ, Hashikawa T. The neuroinvasive potential of SARSCoV2 may play a role in the respiratory failure of COVID-19 patients. $J$ Med Virol 92: 552-555, 2020. doi:10.1002/jmv.25728.

34. Lohman AW, Billaud M, Straub AC, Johnstone SR, Best AK, Lee M, Barr K, Penuela S, Laird DW, Isakson BE. Expression of pannexin isoforms in the systemic murine arterial network. J Vasc Res 49: 405-416, 2012. doi:10.1159/000338758.

35. Lohman AW, Leskov IL, Butcher JT, Johnstone SR, Stokes TA, Begandt D, DeLalio LJ, Best AK, Penuela S, Leitinger N, Ravichandran KS, Stokes KY, Isakson BE. Pannexin 1 channels regulate leukocyte emigration through the venous endothelium during acute inflammation. Nat Commun 6: 7965, 2015. doi:10.1038/ncomms8965.

36. Malik S, Eugenin EA. Role of Connexin and Pannexin containing channels in HIV infection and NeuroAIDS. Neurosci Lett 695: 86-90, 2019. doi:10.1016/j.neulet.2017.09.005.

37. Medina CB, Mehrotra P, Arandjelovic S, Perry JSA, Guo Y, Morioka S, Barron B, Walk SF, Ghesquière B, Krupnick AS, Lorenz U, Ravichandran KS. Metabolites released from apoptotic cells act as tissue messengers. Nature 580: 130-135, 2020. doi:10. 1038/s41586-020-2121-3

38. Mehta P, McAuley DF, Brown M, Sanchez E, Tattersall RS, Manson JJ; HLH Across Speciality Collaboration, UK. COVID-19: consider cytokine storm syndromes and immunosuppression. Lancet 395: 10331034, 2020. doi:10.1016/S0140-6736(20)30628-0.

39. Michalski K, Syrjanen JL, Henze E, Kumpf J, Furukawa H, Kawate T. The Cryo-EM structure of pannexin 1 reveals unique motifs for ion selection and inhibition. eLife 9: e54670, 2020. 10.7554/eLife.54670.

41. Munster VJ, Feldmann F, Williamson BN, van Doremalen N, PérezPérez L, Schulz J, Meade-White K, Okumura A, Callison J, Brumbaugh B, Avanzato VA, Rosenke R, Hanley PW, Saturday G, Scott D, Fischer ER, de Wit E. Respiratory disease in rhesus macaques inoculated with SARS-CoV-2. Nature. In press. doi:10.1038/s41586-020-2324-7.

42. Orellana JA, Velasquez S, Williams DW, Sáez JC, Berman JW, Eugenin EA. Pannexin1 hemichannels are critical for HIV infection of human primary CD4+ T lymphocytes. J Leukoc Biol 94: 399-407, 2013. doi:10.1189/jlb.0512249.

43. Perwitasari O, Yan X, Johnson S, White C, Brooks P, Tompkins SM, Tripp RA. Targeting organic anion transporter 3 with probenecid as a novel anti-influenza a virus strategy. Antimicrob Agents Chemother 57: 475-483, 2013. doi:10.1128/AAC.01532-12.

44. Poyiadji N, Shahin G, Noujaim D, Stone M, Patel S, Griffith B. COVID-19-associated acute hemorrhagic necrotizing encephalopathy: CT and MRI features. Radiology. In press. doi:10.1148/radiol. 2020201187

45. Rahman M, Sun R, Mukherjee S, Nilius B, Janssen LJ. TRPV4 stimulation releases ATP via pannexin channels in human pulmonary fibroblasts. Am J Respir Cell Mol Biol 59: 87-95, 2018. doi:10.1165/rcmb. 2017-0413OC.

46. Ransford GA, Fregien N, Qiu F, Dahl G, Conner GE, Salathe M. Pannexin 1 contributes to ATP release in airway epithelia. Am J Respir Cell Mol Biol 41: 525-534, 2009. doi:10.1165/rcmb.2008-0367OC.

47. Rayner CR, Chanu P, Gieschke R, Boak LM, Jonsson EN. Population pharmacokinetics of oseltamivir when coadministered with probenecid. $J$ Clin Pharmacol 48: 935-947, 2008. doi:10.1177/0091270008320317.

48. Rosli S, Kirby FJ, Lawlor KE, Rainczuk K, Drummond GR, Mansell A, Tate MD. Repurposing drugs targeting the P2X7 receptor to limit 
hyperinflammation and disease during influenza virus infection. $\mathrm{Br} J$ Pharmacol 176: 3834-3844, 2019. doi:10.1111/bph.14787.

49. Seminario-Vidal L, Okada SF, Sesma JI, Kreda SM, van Heusden CA, Zhu Y, Jones LC, O'Neal WK, Penuela S, Laird DW, Boucher RC, Lazarowski ER. Rho signaling regulates pannexin 1-mediated ATP release from airway epithelia. J Biol Chem 286: 26277-26286, 2011. doi:10.1074/jbc.M111.260562.

50. Shahidullah M, Mandal A, Delamere NA. TRPV4 in porcine lens epithelium regulates hemichannel-mediated ATP release and Na-KATPase activity. Am J Physiol Cell Physiol 302: C1751-C1761, 2012. doi:10.1152/ajpcell.00010.2012.

51. Sharma AK, Charles EJ, Zhao Y, Narahari AK, Baderdinni PK, Good ME, Lorenz UM, Kron IL, Bayliss DA, Ravichandran KS, Isakson BE, Laubach VE. Pannexin-1 channels on endothelial cells mediate vascular inflammation during lung ischemia-reperfusion injury. Am J Physiol Lung Cell Mol Physiol 315: L301-L312, 2018. doi:10.1152/ ajplung.00004.2018.

52. Sungnak W, Huang N, Bécavin C, Berg M, Queen R, Litvinukova M, Talavera-López C, Maatz H, Reichart D, Sampaziotis F, Worlock KB, Yoshida M, Barnes JL; HCA Lung Biological Network. SARS-CoV-2 entry factors are highly expressed in nasal epithelial cells together with innate immune genes. Nat Med 26: 681-687, 2020. doi:10.1038/s41591020-0868-6.

53. Séror C, Melki MT, Subra F, Raza SQ, Bras M, Saïdi H, Nardacci R, Voisin L, Paoletti A, Law F, Martins I, Amendola A, Abdul-Sater AA, Ciccosanti F, Delelis O, Niedergang F, Thierry S, Said-Sadier N, Lamaze C, Métivier D, Estaquier J, Fimia GM, Falasca L, Casetti R, Modjtahedi N, Kanellopoulos J, Mouscadet JF, Ojcius DM, Piacentini M, Gougeon ML, Kroemer G, Perfettini JL. Extracellular ATP acts on P2Y2 purinergic receptors to facilitate HIV-1 infection. J Exp Med 208: 1823-1834, 2011. doi:10.1084/jem.20101805.

54. Tang T, Bidon M, Jaimes JA, Whittaker GR, Daniel S. Coronavirus membrane fusion mechanism offers a potential target for antiviral development. Antiviral Res 178: 104792, 2020. doi:10.1016/j.antiviral.2020. 104792.

55. Valdebenito S, Barreto A, Eugenin EA. The role of connexin and pannexin containing channels in the innate and acquired immune response. Biochim Biophys Acta Biomembr 1860: 154-165, 2018. doi:10.1016/j. bbamem.2017.05.015.

56. Vardhana SA, Wolchok JD. The many faces of the anti-COVID immune response. J Exp Med 217: e20200678, 2020. doi:10.1084/jem.20200678.

57. Wang H, Yang P, Liu K, Guo F, Zhang Y, Zhang G, Jiang C. SARS coronavirus entry into host cells through a novel clathrin- and caveolaeindependent endocytic pathway. Cell Res 18: 290-301, 2008. doi:10. $1038 /$ cr.2008.15
58. Ware LB, Matthay MA. The acute respiratory distress syndrome. $N$ Engl $J$ Med 342: 1334-1349, 2000. doi:10.1056/NEJM200005043421806.

59. Wei R, Bao W, He F, Meng F, Liang H, Luo B. Pannexin1 channel inhibitor $\left({ }^{10}\right.$ panx $)$ protects against transient focal cerebral ischemic injury by inhibiting RIP3 expression and inflammatory response in rats. Neuroscience 437: 23-33, 2020. doi:10.1016/j.neuroscience.2020.02.042.

60. Wei R, Wang J, Xu Y, Yin B, He F, Du Y, Peng G, Luo B. Probenecid protects against cerebral ischemia/reperfusion injury by inhibiting lysosomal and inflammatory damage in rats. Neuroscience 301: 168-177, 2015. doi:10.1016/j.neuroscience.2015.05.070.

61. Willebrords J, Maes M, Crespo Yanguas S, Vinken M. Inhibitors of connexin and pannexin channels as potential therapeutics. Pharmacol Ther 180: 144-160, 2017. doi:10.1016/j.pharmthera.2017.07.001.

62. Yang N, Shen HM. Targeting the endocytic pathway and autophagy process as a novel therapeutic strategy in COVID-19. Int J Biol Sci 16: 1724-1731, 2020. doi:10.7150/ijbs.45498.

63. Yang Y, Delalio LJ, Best AK, Macal E, Milstein J, Donnelly I, Miller AM, McBride M, Shu X, Koval M, Isakson BE, Johnstone SR. Endothelial pannexin 1 channels control inflammation by regulating intracellular calcium. J Immunol 204: 2995-3007, 2020. doi:10.4049/ jimmunol.1901089.

64. Zhang C, He H, Wang L, Zhang N, Huang H, Xiong Q, Yan Y, Wu N, Ren H, Han H, Liu M, Qian M, Du B. Virus-triggered ATP release limits viral replication through facilitating IFN- $\beta$ production in a P2X7dependent manner. J Immunol 199: 1372-1381, 2017. doi:10.4049/ jimmunol.1700187.

65. Zhang W, Zhao Y, Zhang F, Wang Q, Li T, Liu Z, Wang J, Qin Y, Zhang X, Yan X, Zeng X, Zhang S. The use of anti-inflammatory drugs in the treatment of people with severe coronavirus disease 2019 (COVID19): the perspectives of clinical immunologists from China. Clin Immunol 214: 108393, 2020. doi:10.1016/j.clim.2020.108393.

66. Zhou F, Yu T, Du R, Fan G, Liu Y, Liu Z, Xiang J, Wang Y, Song B, Gu X, Guan L, Wei Y, Li H, Wu X, Xu J, Tu S, Zhang Y, Chen H, Cao B. Clinical course and risk factors for mortality of adult inpatients with COVID-19 in Wuhan, China: a retrospective cohort study. Lancet 395: 1054-1062, 2020. doi:10.1016/S0140-6736(20)30566-3.

67. Zhou Y, Vedantham P, Lu K, Agudelo J, Carrion R Jr, Nunneley JW, Barnard D, Pöhlmann S, McKerrow JH, Renslo AR, Simmons G. Protease inhibitors targeting coronavirus and filovirus entry. Antiviral Res 116: 76-84, 2015. doi:10.1016/j.antiviral.2015.01.011.

68. Zhu N, Zhang D, Wang W, Li X, Yang B, Song J, Zhao X, Huang B, Shi W, Lu R, Niu P, Zhan F, Ma X, Wang D, Xu W, Wu G, Gao GF, Tan W; China Novel Coronavirus Investigating and Research Team. A novel coronavirus from patients with pneumonia in China, 2019. N Engl J Med 382: 727-733, 2020. doi:10.1056/NEJMoa2001017. 